\title{
Total replacement of soybean oil-meal in growing pig diets : Use of peas supplemented with tryptophan or combined with a lucerne protein concentrate
}

\author{
J.M. PEREZ, D. BOURDON \\ IIV.R.A., Station de Recherches sur lElevage des Porcs, \\ Centre de Rennes-Saint-Gilles, F 35590 L'Hermitage
}

Many studies carried out in France the last few years have shown that incorporation of large amounts of peas ( $30 \mathrm{p}$. 100 and more) in growing pig diets generally leads to a lower performance.

Two successive experiments were made with 48 and 60 fattening pigs, respectively, kept in individual pens and with a live weight of $25-28$ to $100 \mathrm{~kg}$, in order to study :

- the possibilities of incorporating a very high level of peas $(40 \mathrm{p} .100)$ as only source of supplementary protein to simplified diets based on maize (trials 1 and 2);

- the effects of L-tryptophan supplementation of diets based on peas : 0.03 p. 100 during the growing period only (trial 1) or 0.05 p. 100 during the whole fattening period (trial 2) ;

- combinations of peas $(30$ or 40 p. 100) with a lucerne protein concentrate (10 or 5 p. 100) used as natural source of tryptophan (trial 2).

As compared to control diets (maize-soybean oil-meal), the utilization of peas (winter variety Frisson) as only protein supplement led in both trials to a marked decline in the performance of the animals, especially during the growing period $(-15$ p. 100 for feed intake and -40 p. 100 for weight gain). Addition of tryptophan allowed to restore almost totally the level of feed intake and considerably improved the growth rate and feed efficiency. Thus, in trial 2 with diets (maize-peas) rebalanced with tryptophan during the whole growing period, performances were only $6 \mathrm{p}$. 100 lower than those of the control group (non significant difference). In the same way, the combination of peas and $\mathbf{P X}_{1}$ without soybean oil-meal led to performances equivalent to those obtained with maize-peas diets supplemented with tryptophan over the whole period $(28-100 \mathrm{~kg})$ and even identical to those of the control group during the finishing period.

Results of both trials clearly indicate the role of tryptophan as first limiting factor in diets containing a high proportion of peas and point out the possibilities of using several protein sources of metropolitan origin to totally replace soybean in growing pig diets.

\section{Energy and protein value of French low glucosinolate dehulled rapeseed oil-meal in pigs Comparison with a normal commercial rapeseed oil-meal}

\author{
D. BOURDON*, Pascale QUERE**, J.J. BAUDET *** \\ *I.N.R.A.. Station de Recherches : ur l'Elevage des Porcs, \\ Centre de Rennes-Saint-Gilles, $F 35590$ L'Hermitage \\ :* Université de Rennes, U.E.R. Sciences biologiques, \\ Laboratoire de Physiologie des Régulations, F 35000 Rennes \\ :*:* C.E.T.I.O.M., Services d'Etudes et Recherches, Section Technologie, \\ Rue Monge, F 33600 Pessac
}

A digestibility trial was made to estimate the energy and protein value of 3 types of rapeseed oil-meals exhibiting the following characteristics (expressed in percent of dry matter) : 
- a normal commercial rapeseed oil-meal :

dry matter : 90 ; total crude protein : 39.0 ; fat : 2.7 ; ashes : 7.5 ; crude fibre : 12.2 ; I.T.C. (*) : 2.2 ; T.O.V. $\left({ }^{*}\right): 5.2$; gross energy $\mathrm{kcal} / \mathrm{kg}$ D.M. : 4664 ;

- a normal French low glucosinolate rapeseed oil-meal (Normal French Zerothio) :

dry matter : 89.5 ; total crude protein : 37.9 ; fat : 2.5 ; ashes : 7.5 ; crude fibre : 15.4 ; I.T.C. (*) : 0.85 ; T.O.V. $\left(^{*}\right): 1.58$; gross energy kcal/kg D.M. : 4664 ;

- A French low glucosinolate dehulled rapeseed oil-meal (Dehulled French Zerothio) :

dry matter : 90.2 ; total crude protein : 42.1 ; fat : 7.2 ; ashes : 7.2 ; crude fibre : 6.9 ; I.T.C. $\left(^{*}\right)$ : 1.48 ; T.O.V. $\left({ }^{*}\right): 2.38$; gross energy kcal/kg D.M. : 4900 .

The trial involved 16 castrated male pigs with a mean live weight of $59.8 \mathrm{~kg}$ distributed into 4 groups and housed in individual pens. Faecal collection was made during 10 consecutive days. The energy and protein value of rapeseed oil-meals was assessed using the substitution method with simplified diets based on maize, containing 10 p. 100 normal commercial rapeseed oil-meal (group 2) and 20 p. 100 normal French Zerothio rapeseed oil-meal (group 3) or dehulled (group 4). Group 1 received a diet only based on maize.

The digestible energy values estimated for the 3 types of rapeseed oil-meals, normal commercial, normal French Zerothio, and dehulled French Zerothio were 3569,3462 and $4181 \mathrm{kcal} / \mathrm{kg}$ D.M., corresponding to apparent energy digestibility coefficients of 77.1 ; 74.2 and 85.3. The apparent protein digestibility coefficients were 76.1 p. 100 for the commercial normal rapeseed oil-meal, 79.7 p. 100 for the normal French Zerothio and 88.1 p. 100 for the dehulled French Zerothio.

Our results showed that the apparent protein digestibility coefficient of the French low glucosinolate rapeseed oil-meal was improved by 5 p. 100 as compared to the normal commercial rapeseed oil-meal, but the most significant result was the large improvement of the nutritional value of the French low glucosinolate dehulled rapeseed oil-meal ( 20 p. 100 for digestible energy and 15 p. 100 for protein A.D.C. mainly due to a reduction by 8.5 points of its crude fibre content as compared to normal rapeseed oil-meal.

\title{
Utilization of sweet kalina lupin seed in weaned piglets and growing-finishing pigs
}

\author{
J. CASTAING *, R. COUDURE *, J. FEKETE **, F. GROSJEAN **, \\ M. LEUILLET ** \\ *Association générale des Producteurs de Maïs, \\ 122 , boulevard Tourasse, F 64000 Pau \\ ** Institut technique des Céréales et des Fourrages, \\ 8, avenue du Président-Wilson, F 75116 Paris
}

Two experiments were made in young piglets of 8.4 to $23 \mathrm{~kg}$ and in bacon pigs of 26.3 to $104 \mathrm{~kg}$ in order to study the effect of relatively low levels in incorporation of white soft lupin of the variety Kalina. The maximum level was 10 points for piglets and 15 points for bacon pigs.

In piglets, utilization of lupin in diets offered as a meal containing $3150-3200 \mathrm{kcal}$ D.E. and supplying $360 \mathrm{~g}$ lysine for $1000 \mathrm{kcal}$ digestible energy did not allow to reach the performance obtained with the control diet. An almost linear decrease in the feed intake ranging around 15 p. 100 , was observed with the level of 10 points lupin. Growth rates were reduced less than proportional to the levels of feed intake since the feed conversion ratio was slightly improved by the presence of lupin.

(*) Expressed in $\mathrm{mg} / \mathrm{g}$ of defatted dry matter. 